\title{
Pengaruh Konsentrasi Ruthenium (N719) sebagai Fotosensitizer dalam Dye-Sensitized Solar Cells (DSSC) Transparan
}

\author{
Hardani, ${ }^{*}$ Hendra, Muh. Iman Darmawan, Cari, dan Agus Supriyanto \\ Jurusan Fisika, FMIPA Universitas Sebelas Maret Surakarta, Jl. Ir. Sutami No. 36 A, Surakarta 57126
}

\begin{abstract}
Intisari
DSSC (Dye-sensitized solar cells) adalah suatu devais yang mampu mengubah energi matahari menjadi energi listrik dengan memanfaatkan dye ruthenium (N719) sebagai sensitizer. Pada penelitian ini telah berhasil dibuat elektroda kerja berbahan titanium dioksida $\left(\mathrm{TiO}_{2}\right)$ ukuran nanopartikel berbentuk lapisan yang dideposisikan diatas gelas transparan konduktif FTO (fourine doped-tin oxide) dengan metode spin coating. Dari hasil pengujian menggunakan solar simulator AM $1.5 \mathrm{G}\left(100 \mathrm{~mW} / \mathrm{cm}^{2}\right)$ diperoleh overall conversion efficiency mencapai $0,298 \%$ dengan tegangan open circuit $\left(\mathrm{V}_{o c}\right)$ sebesar $460 \mathrm{mV}$, rapat arus short circuit $\left(\mathrm{J}_{s c}\right)$ sebesar 7,5 mA dengan fill factor (FF) 0,24 .
\end{abstract}

\begin{abstract}
DSSC (Dye-sensitized solar cells) is a firmware device capable of converting solar energy into electrical energy by utilizing a ruthenium dye (N719) as a sensitizer. In this research has been successfully made the working electrode is made of titanium dioxide ( $\mathrm{TiO}_{2}$ ) nanoparticles size shaped thin film is deposited on a transparent conductive glass FTO (fourine-doped tin oxide) by the spin coating method. From the test results using AM $1.5 \mathrm{G}$ solar simulator $\left(100 \mathrm{~mW} / \mathrm{cm}^{2}\right)$ obtained overall conversion efficiency reached $0.298 \%$ with an open circuit voltage $\left(\mathrm{V}_{o c}\right)$ of $460 \mathrm{mV}$, short circuit current density $\left(\mathrm{J}_{s c}\right)$ of $7.5 \mathrm{~mA}$ with a fill factor $(\mathrm{FF}) 0.24$.
\end{abstract}

KATA KUNCI: dye-sensitized solar cell (DSSC), sensitizer, Fourine-doped tin oxide (FTO) http://dx.doi.org/10.12962/

\section{PENDAHULUAN}

Energi merupakan kebutuhan yang sangat penting dalam memenuhi segala bentuk kebutuhan hidup di dunia, sehingga kebutuhan energi di dunia semakin hari semakin meningkat. Oleh sebab itu, pencarian sumber energi alternatif yang dapat diperbaharui (renewable), murah dan ramah lingkungan menjadi tuntutan yang tidak dapat ditunda lebih lama lagi saat ini sehubungan dengan menyusutnya cadangan bahan bakar fosil secara siginifikan dalam beberapa tahun belakangan ini, serta efek rumah kaca dan pemanasan global yang ditimbulkan selama proses pengunaannya. Kementerian Energi dan Sumber Daya Mineral (ESDM) Republik Indonesia memperkirakan cadangan minyak bumi di tanah air hanya mencukupi untuk 18 tahun ke depan, sementara gas bumi dan batubara masingmasing hingga 61 dan 147 tahun ke depan [1]. Salah satu energi alternatif yang mempunyai potensi sangat besar namun belum dimanfaatkan secara maksimal adalah sel surya (photovoltaic/solar cell) yang mampu mengkonversi sinar matahari secara langsung menjadi energi listrik. DSSC berbeda dengan sel surya komersial berbasis silikon, dimana pada sel surya DSSC ini terjadi pemisahan antara fungsi penyerapan cahaya dengan transport pembawa muatannya [2], DSSC memiliki

\footnotetext{
*E-MAIL: danylastchild07@gmail.com
}

beberapa keunggulan dibandingkan dengan sel surya komersial berbasis silikon diantaranya murah, pembuatannya mudah, serta memiliki efisiensi tinggi walau pada intensitas cahaya yang kurang [3]. Komponen-komponen didalam DSSC pada umumnya terdiri dari elektroda kerja berupa elektroda foto-anoda dari bahan semikonduktor (misalkan: $\mathrm{TiO}_{2}$ dan $\mathrm{ZnO}$ ), dye sebagai sensitizer yang menyerap cahaya matahari, pasangan redox berupa triodide/iodide, dan counter elektroda berbahan Platina (Pt). Sedangkan kelemahan dari sel surya berbasis silikon tidak hanya harganya yang mahal, juga spektrum penyerapan terlalu sempit. Diketahui distribusi energi dari sinar matahari terdiri sekitar $4 \%$ ultraviolet dan cahaya tampak 96\%. Spektrum utama penyerapan sel surya silikon adalah ultraviolet dan ungu. Ini menunjukkan sel surya silikon tidak dapat menggunakan hampir $96 \%$ energi dari cahaya matahari [4]. Upaya untuk memperluas spektrum serapan dari daerah ultraviolet hingga wilayah cahaya tampak sekarang diaplikasikan sebagai Dye Sensitized Solar Cell [5], dimana pewarna (dye) dapat membantu DSSC untuk memperluas spektrum penyerapan [6].

Kesulitan teknis pengembangan DSSC untuk memperpanjang masa pakai DSSC dan meningkatkan penyerapan kuantitas cahaya matahari, karena pewarna organik dengan mudah akan busuk. Semua pertanyaan untuk dye adalah sangat menarik dan layak untuk dipelajari [7]. Penelitian menyajikan beberapa data eksperimen dari dye ruthenium (N719) yang digunakan sebagai bahan sensitizer. Analisis bahan di- 
lakukan pada sifat optik dan listrik bahan organik sintesis dari dye ruthenium (N719). Hasil ekstrak dari dye ruthenium (N719) yang digunakan dalam penelitian menunjukkan absorbansi kisaran 300-600 nm. Metode yang umum digunakan untuk membuat thin lapisan $\mathrm{TiO}_{2}$ adalah dengan melapiskan pasta nanopartikel $\mathrm{TiO}_{2}$ di atas gelas transparan konduktif (gelas FTO) menggunakan metode doctor blade / Slip Casting. Namun metode ini memiliki kelemahan, sulit mendapatkan lapisan dengan ketebalan yang konsisten. Pada penelitian ini menggunakan metode spin coating, dengan metode ini terbukti menghasilkan lapisan dengan ketebalan terkontrol dan memiliki homogenitas tinggi serta proses yang simpel [8]. Ketebalan lapisan yang terkontrol memungkinkan untuk mendapatkan lapisan dengan pengulangan yang konsisten. Untuk mendapatkan DSSC dengan efisiensi tinggi, ketebalan lapisan pada elektroda foto-anoda $\mathrm{TiO}_{2}$ yang optimum karena ketebalan lapisan ini mempengaruhi proses penyerapan cahaya [9].

\section{EKSPERIMEN}

Penelitian ini bertujuan untuk mengetahui untuk memperoleh karakterisasi sifat optik (spektrum absorbansi) dan sifat listrik (fotokonduktivitas) dari dye Ruthenium (N719) dan pengaruh variasi konsentrasi larutan Ruthenium (N719) terhadap kinerja DSSC. Analisis dilakukan pada sifat optik, sifat listrik dye Ruthenium (N719) dan karakteristik arus-tegangan (I-V) DSSC. Hasil optimasi kinerja DSSC dilakukan pengujian ulang menggunakan Keithley I-V meter. Ekstraksi diuraikan pada sub bagian berikut.

\section{Pembuatan Dye Ruthenium (N719)}

Dye yang digunakan dalam penelitian ini adalah ruthenium kompleks (N719). Dye ruthenium divariasi konsentrasinya yaitu $0,1 \%$ wt, $0,5 \%$ wt dan $1 \%$ wt. Untuk membuat dye Ruthenium (N719) 0,1\% sebanyak 0,0005 gram dicampurkan dengan pelarut etanol sebanyak $5 \mathrm{ml}$, dye Ruthenium (N719) $0,5 \%$ sebanyak 0,0025 gram dicampurkan dengan pelarut etanol sebanyak $5 \mathrm{ml}$ dan untuk dye Ruthenium (N719) $1 \%$ sebanyak 0,005 gram dicampurkan dengan pelarut etanol sebanyak $5 \mathrm{ml}$ kemudian masing-masing sampel diaduk menggunakan vortex stirrer dengan kecepatan 200-300 rpm selama kurang lebih 30 menit. Setelah itu, larutan N719 di-sonicator selama kurang lebih 15 menit sampai larutan homogen. Pengadukan dilakukan menggunakan gelombang ultrasonic yang dihasilkan oleh ultrasonic cleaner.

Untuk keperluan pengujian sifat optik, larutan Ruthenium (N719) dengan masing-masing konsentrasi dilapiskan ke atas kaca preparat dengan menggunakan metode perendaman. Sedangkan untuk keperluan pengujian sifat listrik, larutan ruthenium (N719) dengan masing-masing konsentrasi di uji dengan menggunakan El-kahfi meter. Setelah diaduk kemudian didiamkan selama 24 jam dan simpan larutan dalam wadah tertutup dan terlindung dari sinar matahari.

\section{Karakterisasi Absorbansi Ruthenium (N719)}

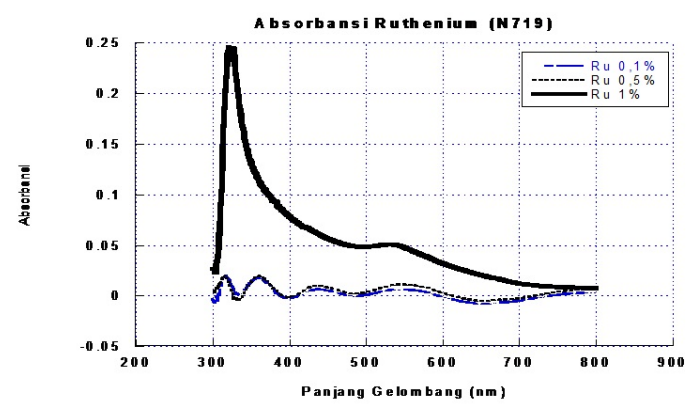

Gambar 1: Grafik Absorbansi Ruthenium (N719).

Absorbansi Ruthenium (N719) diukur menggunakan Spectroscopy UV-Vis pada rentang panjang gelombang 300-800 nm. Absorbansi Ruthenium (N719) dengan variasi konsentrasi $0,1 \%, 0,5 \%$ dan $1 \%$ untuk mengetahui pengaruh peningkatan konsetrasi terhadap efisiensi DSSC.

\section{Konduktivitas Dye Ruthenium (N719)}

Pengukuran konduktivitas menggunakan Elkahfi 100/IVMeter dilakukan dalam keadaan gelap dengan menutup semua bagian wadah menggunakan aluminium foil dan di bawah penyinaran menggunakan sumber cahaya lampu halogen 100 $\mathrm{mW} / \mathrm{cm}^{2}$ dan energi intensitas $680,3 \mathrm{~W} / \mathrm{m}^{2}$. Lampu halogen digunakan karena memiliki spektrum penuh yang mirip cahaya tampak dengan sinar matahari. Dari hasil pengukuran I-V kemudian ditentukan konduktivitas $(\sigma)$ bahan.

Untuk menentukan konduktivitas larutan organik dapat menggunakan persamaan:

$$
\begin{aligned}
\rho & =\frac{R A}{\ell} \\
\sigma & =\frac{1}{\rho}=\frac{\ell}{R A}
\end{aligned}
$$

dengan $\sigma$ adalah konduktivitas $\left(\mathrm{ohm}^{-1} \cdot \mathrm{m}^{-1}\right)$, R adalah resistansi (Ohm), $\ell$ adalah jarak antara dua elektroda (m) dan A adalah penampang permukaan daerah elektroda $\left(\mathrm{m}^{2}\right)$.

\section{HASIL DAN PEMBAHASAN}

Penelitian menggunakan dye ruthenium (N719) yang dilarutkan dalam etanol. Kemudian diuji absorbansi menggunakan Spectrofotometer UV Visible shimadzhu 1601 PC dan pengukuran Arus-Tegangan menggunakan I-V meter/elkahfi 100 dari I-V meter untuk mengetahui nilai konduktivitas elektrolit dan dye. Absorbansi Ruthenium (N719) diukur menggunakan Spectroscopy UV-Vis pada rentang panjang gelombang 300-800 nm. Gambar 1 menunjukkan grafik absorbansi Ruthenium (N719) dengan variasi konsentrasi $0,1 \%, 0,5 \%$ dan $1 \%$.

Absorbansi Ruthenium (N719) pada penelitian ini memiliki puncak serapan pada rentang panjang gelombang 300-600 


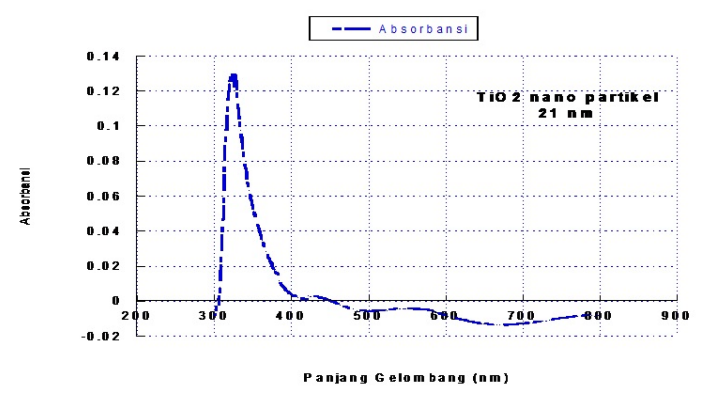

Gambar 2: Grafik Absorbansi $\mathrm{TiO}_{2}$ Nanopartikel.

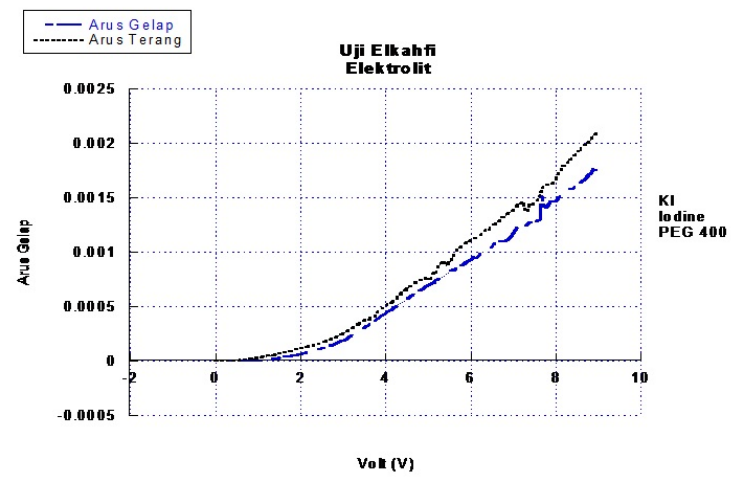

Gambar 3: Kurva Konduktivitas Elektrolit.

nm (Gambar 1). Hasil yang sama diperoleh pada penelitian Gratzel [11], Alam et al. [13] dan Lee et al. [10], dengan demikian Ruthenium (N719) mampu menyerap cahaya pada rentang panjang gelombang cahaya tampak (visible).

Pada Gambar 2, $\mathrm{TiO}_{2}$ memiliki puncak serapan pada rentang panjang gelombang $300-400 \mathrm{~nm}$. Hasil yang sama juga diperoleh Hong, et al. [14]. Hal ini menunjukkan bahwa $\mathrm{TiO}_{2}$ mampu menyerap cahaya pada rentang ultraviolet. Dalam DSSC $\mathrm{TiO}_{2}$ berfungsi sebagai perangkap elektron dari pita konduksi Ruthenium (N719). Selain itu $\mathrm{TiO}_{2}$ memiliki energi gap $3 \mathrm{eV}$ [12], sehingga dibutuhkan energi sama atau lebih besar dari $3 \mathrm{eV}$ agar elektron dapat dieksitasi dari pita valensi ke pita konduksi $\mathrm{TiO}_{2}$. Sedangkan untuk nilai konduktivitas dari elektrolit dapat di lihat pada Gambar 3. Gambar 3 dan Tabel I, merupakan kurva dan hasil pengujian karakteristik I-V eletrolit pasangan redoks iodine dan kalium iodide yang dilarutkan dalam larutan PEG 400 pada kondisi terang dan pada kondisi gelap.

Untuk lebih jelasnya data disajikan pada Tabel I.

Nilai konduktivitas eletrolit pada kondisi gelap $(1,76$

TABEL I: Hasil Konduktivitas Elektrolit.

\begin{tabular}{ccc}
\hline \hline Bahan & \multicolumn{2}{c}{ K ond u k ivi t a s } \\
& Gelap $\left(\Omega^{-1} \mathrm{~m}^{-1}\right)$ Terang $\left(\Omega^{-1} \mathrm{~m}^{-1}\right)$ \\
\hline Elektrolit & $1,76 \times 10^{-3}$ & $2,10 \times 10^{-3}$ \\
\hline
\end{tabular}

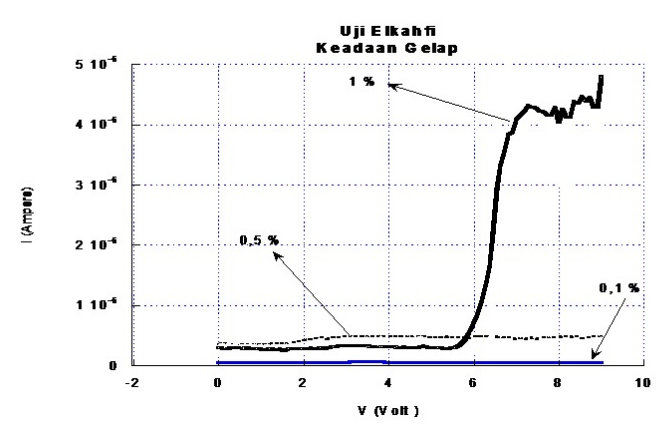

Gambar 4: Grafik I-V dye Ruthenium (N719) konsentrasi 0,1\%, $0,5 \%$ dan $1 \%$ pada keadaan gelap.

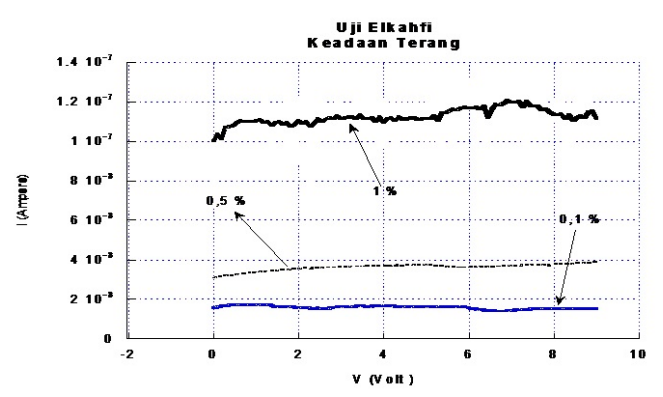

Gambar 5: Grafik I-V dye Ruthenium (N719) konsentrasi 0,1\%, $0,5 \%$ dan $1 \%$ pada keadaan terang.

$\left.\times 10^{-3} \Omega^{-1} \mathrm{~m}^{-1}\right)$ dan meningkat menjadi $\left(2,1 \times 10^{-3}\right.$ $\Omega^{-1} \mathrm{~m}^{-1}$ ) pada kondisi disinari cahaya. Besarnya konduktivitas yang diharapkan dapat meningkatkan hasil performa kerja pada DSSC. Ruthenium (N719) diuji sifat kelistrikannya menggunakan El Kahfi I-V meter. El Kahfi I-V meter bekerja dengan prinsip memberikan tegangan masukan pada sampel melalui elektroda sehingga dihasilkan arus. Karakterisasi sifat listrik bertujuan untuk mengetahui konduktivitas dari dye Ruthenium (N719).

Gambar 4 menunjukkan kurva I-V dye Ruthenium (N719) dengan variasi konsentrasi $0,1 \%, 0,5 \%$ dan $1 \%$ pada keadaan gelap. Kurva I-V dye Ruthenium (N719) 1\% memiliki slope kurva lebih tingi dibandingkan konsentrasi $0,1 \%$ dan $0,5 \%$. Berdasarkan kurva I-V tersebut dapat dilihat bahwa arus yang dihasilkan berbanding lurus terhadap konsentrasi dari dye Ruthenium (N719).

Gambar 5 menunjukkan hasil kurva I-V dye Ruthenium (N719) dengan variasi konsentrasi $0,1 \%, 0,5 \%$ dan $1 \%$ pada keadaan terang. Berdasarkan kurva tersebut dye Ruthenium (N719) memperlihatkan karakterisasi I-V yang sama saat diukur pada keadaan gelap, kurva I-V dye Ruthenium (N719) $1 \%$ memiliki slope kurva lebih tinggi dibandingkan konsentrasi $0,5 \%$ dan $0,1 \%$. Hal ini menunjukkan bahwa penambahan konsentrasi dye Ruthenium (N719) meningkatkan nilai arus secara linear.

Berdasarkan hasil karakterisasi I-V dye Ruthenium (N719), diperoleh kurva I-V pada keadaan gelap (Gambar 4) dan 
TABEL II: Nilai konduktivitas dye Ruthenium (N719).

\begin{tabular}{ccc}
\hline \hline $\begin{array}{c}\text { Konsentrasi } \\
\text { dye Ruthenium (N719) }\end{array}$ & \multicolumn{2}{c}{ Konduktivitas $\left(\Omega^{-1} \mathrm{~m}^{-1}\right)$} \\
& Keadaan gelap Keadaan terang \\
\hline $0,1 \%$ & $5,73 \times 10^{-8}$ & $1,10 \times 10^{-7}$ \\
$0,5 \%$ & $5,45 \times 10^{-7}$ & $6,94 \times 10^{-7}$ \\
$1 \%$ & $1,51 \times 10^{-6}$ & $1,42 \times 10^{-7}$ \\
\hline \hline
\end{tabular}

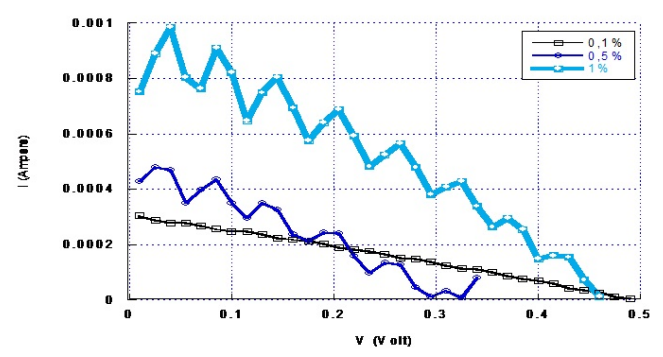

Gambar 6: Kurva I-V DSSC variasi konsentrasi dye ruthenium (N719) dengan pelarut etanol menggunakan platina sebagai elektroda lawan.

keadaan terang (Gambar 5). Nilai arus yang dihasilkan dye Ruthenium (N719) meningkat secara linier ketika nilai tegangan bertambah. Seiring dengan penambahan jumlah konsentrasi dye Ruthenium (N719), akan semakin banyak pula molekul dye Ruthenium (N719) yang menghasilkan elektron bebas. Elektron bebas ini yang akan menghasilkan aliran muatan, sehingga akan menimbulkan arus. Karakteristik tersebut muncul pada keadaan gelap maupun terang.

Kurva I-V dye Ruthenium (N719) kondisi gelap dan terang dapat digunakan untuk menentukan besaran konduktivitas menggunakan Pers.(2). Nilai konduktivitas dye Ruthenium (N719) kondisi gelap dan terang disajikan pada Tabel II.

Dari Tabel II menunjukkan bahwa dye ruthenium (N719) memiliki kemampuan untuk menghasilkan arus listrik yang baik.

Pengujian performa DSSC variasi konsentrasi dye Ruthenium (N719) dilakukan untuk melihat pengaruh konsentrasi terhadap performa yang dihasilkan DSSC. Pengujian ini dilakukan pada kondisi menggunakan platina sebagai elektroda lawan.

Gambar 6 menunjukkan kurva I-V DSSC yang menggunakan dye Ruthenium (N719) dengan pelarut etanol menggunakan platina sebagai elektroda lawan. Berdasarkan gambar tersebut dapat dilihat bahwa DSSC yang menggunakan dye Ruthenium (N719) dengan konsentrasi 1\% menghasilkan slope paling tinggi dibandingkan dengan DSSC yang menggunakan dye Ruthenium (N719) dengan konsentrasi 0,5\% dan $0,1 \%$. Hal ini mengindikasikan bahwa perubahan konsentrasi dye Ruthenium (N719) pada sel ini berpengaruh secara signifikan terhadap peningkatan $\mathrm{I}_{s c}$ dan $\mathrm{V}_{o c}$.

Berdasarkan hasil optimasi, DSSC yang menghasilkan performa terbaik adalah yang menggunakan dye Ruthenium (N719) 1\% dengan pelarut etanol dan menggunakan platina

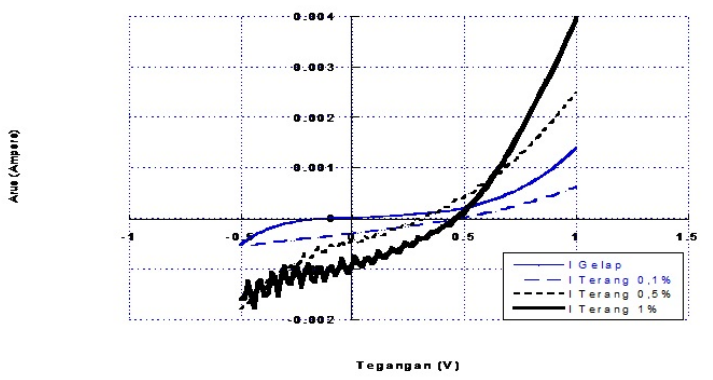

Gambar 7: Kurva I-V DSSC hasil optimasi.

TABEL III: Efisiensi DSSC hasil optimasi.

\begin{tabular}{cccc}
\hline \hline Ruthenium (N719) & $\mathrm{V}_{o c}(\mathrm{mV})$ & $\mathrm{I}_{s c}(\mathrm{~mA})$ & $\eta(\%)$ \\
\hline & & & \\
$0,1 \%$ & 490 & 0,36 & 0,103 \\
$0,5 \%$ & 340 & 0,428 & 0,098 \\
$1 \%$ & 460 & 0,75 & 0,298 \\
\hline \hline
\end{tabular}

(Pt) sebagai elektroda lawan. DSSC dengan variasi ini diuji lagi dengan Keithley $\mathrm{I}-\mathrm{V}$ meter dengan penerangan lampu halogen dengan variasi intensitas pencahayaan dari 100 $\mathrm{W} / \mathrm{m}^{2}, 250 \mathrm{~W} / \mathrm{m}^{2}, 500 \mathrm{~W} / \mathrm{m}^{2}, 750 \mathrm{~W} / \mathrm{m}^{2}$, dan $1000 \mathrm{~W} / \mathrm{m}^{2}$.

Gambar 7 menunjukkan kurva I-V DSSC hasil optimasi. Berdasarkan Gambar 7 dapat dilihat pada saat konsentrasi dinaikkan dari $0,1 \%, 0,5 \%$ sampai dengan $1 \%$, arus yang dihasilkan juga semakin meningkat. Hal ini mengindikasikan bahwa peningkatan konsentrasi menyebabkan arus meningkat dan secara otomatis dapat meningkatkan efisiensi dari DSSC. Nilai efisiensi DSSC hasil optimasi disajikan pada Tabel III.

Tabel III menyajikan efisiensi dari masing-masing DSSC dengan variasi konsentrasi yang berbeda pada saat intensitas pencahayaan yang sama yaitu $500 \mathrm{~W} / \mathrm{m}^{2}$. Dari Tabel III dapat dilihat bahwa DSSC yang menghasilkan performa terbaik adalah DSSC yang menggunakan dye Ruthenium (N719) dengan konsentrasi $1 \%$ dan menghasilkan efisiensi sebesar $0,298 \%$. Hal ini mengindikasikan bahwa semakin meningkatnya konsentrasi dye dapat mempengaruhi efisiensi dari DSSC.

\section{SIMPULAN}

1. Pengukuran dan analisis penyerapan spektrum absorbansi dye Ruthenium (N719) telah dilakukan dengan variasi konsentrasi dan intensitas penyinaran. Hasil penelitian menunjukkan bahwa dye Ruthenium (N719) tersebut memiliki spektrum penyerapan di panjang gelombang antara 300-600 nm,

2. Pengukuran I-V Meter/Elkahfi digunakan sumber tegangan sama sebesar 9 volt menghasilkan arus listrik dari larutan elektrolit lebih besar. Arus dalam keadaan gelap memberikan $1,76 \times 10^{-3} \Omega^{-1} \mathrm{~m}^{-1}$, sedangkan pada keadaan terang memberikan $2,10 \times 10^{-3}$ $\Omega^{-1} \mathrm{~m}^{-1}$, 
3. Hasil pengukuran absorbansi mulai yang terbesar sampai terkecil yaitu dye ruthenium (N719) $1 \%$, dye ruthenium (N719) 0,5\% dan dye ruthenium (N719) 0,1\%. Hal ini menjadikan bahan organik perlu untuk di selidiki sebagai bahan sensitizer DSSC,

4. Efisiensi yang tertinggi dihasilkan oleh dye ruthenium (N719) $1 \%$ sebesar 0,298\%,

5. Peningkatan konsentrasi dye ruthenium (N719) dapat mempengaruhi kinerja dari DSSC.

\section{Ucapan Terima Kasih}

Peneliti mengucapkan terimakasih kepada pengelola Laboratorium MIPA UNS Surakarta dan dukungan dari LPPM hibah pasca UNS Surakarta dengan No. 301A/ UN27/ PN/ 2014.
[1] T. Priyambodo, Pembangkit Listrik Tenaga Surya: Memecah Kebuntuan Kebutuhan Energi Nasional dan Dampak Pencemaran Lingkungan, URL: http://www.chem-istry. org/?sect=artikel\&ext=114 (Diakses 15 Juli 2014).

[2] A. Hagfeldt, et al., Solar Energy Mater. And Solar Cells, 31, 481-488 (1994).

[3] T. Ma, et al., Nano Letters, 5, 2543-2547 (2005).

[4] T.-W. Lin, et al., Absorption Spectra Analysis of Natural Dyes for Applications in Dye-Sensitized Nano Solar Cells, The 31st National Conference on Theoretical and Applied Mechanics, December 21-22, 2007, ISU, Kaohsiung, Taiwan, R.O.C., 2007.

[5] M.Grtzel, C.R. Chimie, 9, 578-583 (2006).

[6] M. Grtzel, Journal of Photochemistry and Photobiology C: Photochemistry Reviews, 4, 145-153 (2003).

[7] K. Kalyanasundaram, Gratzel M., Coordination Chemistry Reviews, 77, 347-414 (1998).
[8] A. Purwanto, H. Widiyandari, and A. Jumari, Thin solid Film, 520, 2092-2095 (2012).

[9] S. Agarwala, et al., ACS Applied Materials \& Interfaces, 2, 1844-1850 (2010).

[10] C.-L. Lee, W.-H Lee, C.-H. Yang, International Journal of Photoenergy (2013).

[11] M. Grtzel, Michael, 2005. Photovoltaic performance and longterm stability of dye-sensitized meosocopic solar cells. C.R. Chimie 9 (2006) 578-583.

[12] S. Karuppuchamy, and J.M. Jeong, J. Oleo Sci., 55, 264-266 (2006).

[13] R.Z. Alam, dkk., Potensi Sumber Energi Terbarukan untuk Permintaan Energi Berkelanjutan dari Malaysia: A Review, Jurnal Penelitian Ilmu Terapan, 10(6), 212-220 (2015).

[14] S.S. Hong, et al., Mater. Lett., 57, 2975- 2979 (2003). 